\title{
Pedagogical problems encountered by teachers of English to Computer Science students in the Indonesian context
}

\author{
1,2Fransisca Endang Lestariningsih*, ${ }^{2}$ Suwarsih Madya, ${ }^{3}$ Joko Nurkamto \\ ${ }^{1}$ English Language Education Department, Universitas Kristen Duta Wacana, Indonesia \\ ${ }^{2}$ English Language Education Department, Universitas Negeri Yogyakarta, Indonesia \\ ${ }^{3}$ English Language Education Department, Universitas Sebelas Maret, Indonesia
}

*Corresponding Author

Email: endang@staff.ukdw.ac.id

\begin{abstract}
Many factors are required in order to increase the skills of English of higher education students, specifically computer science students. Of the factors, teachers play a very important role since they are the agents of change in the classrooms; not to neglect that the students are also the agents of their own changes. Using Brown's 12 pedagogical characteristics of a good language teacher as its theory, this is a report of the first step of designbased research, practical problems encountered by teachers of English to computer science students conducted at two private universities in Indonesia. Among the 12 characteristics, knowledge of approaches to language teaching seems to be the biggest challenge that came upon the teachers. The findings of this step will subsequently be used as the bases to go further to the second cycle of design-based research, which is the development of solutions informed by existing design principles and technological innovations.
\end{abstract}

Keywords: pedagogical characteristics; design-based research; teacher of English for computer science

$\begin{array}{llll}\text { Received: } & \text { Revised: } & \text { Accepted: } & \text { Published: } \\ \text { 22 May 2019 } & \text { 1 February 2020 } & \text { 3 February 2020 } & \text { 29 February 2020 }\end{array}$

\section{INTRODUCTION}

A tracer study conducted by a team from a private university in Yogyakarta, Indonesia in 2016, showing the level of satisfaction of the users of that university graduates, demonstrates that the university has not yet maximally fulfilled the users' requirement of English mastery (Universitas Kristen Duta Wacana, 2016). Only $10 \%$ and $29 \%$ of the graduates' users said they were 
highly satisfied and satisfied respectively; whereas $57 \%$ of the respondents admitted that the English skills of the graduates were sufficient and the other $4 \%$ said they were dissatisfied. The result of the survey illustrates that there is a need to increase the English skills of the students, and as one of the departments, the Computer Science Department is included. In 2016 the number of computer science students at the university was 677 out of around 3,800 students (about 18\% of the student body). It outnumbered the other departments at the university, which only had less than $10 \%$ of the student body. It indicated that improving the English skills of computer science students will quite-highly contribute to the users' satisfaction with the graduates of that university.

The tracer study finding, mentioned previously, leads to the necessity to increase the students' English skills. Many factors are required in order to increase the English skills of higher education students, especially students in a computer science department. These include the motivation of the students, the competence of the teachers, the facilities, and the learning environments. Of the factors mentioned, teachers are considered as the most important since they are the agents of change in the classrooms, not to neglect that the students are also the agents of their own changes. Creative teachers, who can manage the class and find suitable instructional methods and materials and who can be sensitive in adapting to the changing in the world, are probably highly successful in improving the English skills needed for computer science students. Such teachers should understand the pedagogical and andragogical aspects of the higher education learners, particularly in the context of $21^{\text {st }}$ century education that needs skills to equip the students with higher order thinking (HOT) skills rather than lower order thinking (LOT) ones.

In line with the idea of HOT and LOT, Miri, David \& Uri (2007) acknowledge that in the ever-changing and challenging world, students, as future citizens, are demanded to be able to see beyond their school of capacity. They argue that students need to develop their HOT skills such as critical thinking, decision making, and problem-solving. Thus teachers should also experience themselves of the pedagogical and andragogical learning to improve their competences, especially in HOT skills rather than emphasizing LOT skills. Richards and Lockhart (2007) mentioned that one of the roles of a teacher is a motivator who "seeks to improve students' confidence and interest in learning and to build a classroom climate that will motivate students." (p. 106). In line with that, Organization for Economic Co-operation and Development (OECD) constantly disseminates a message that "Highly qualified and competent teachers are the key for excellent education systems" (Guerriero, 2017). Once they experience what will be faced by the students, it is expected that the teachers will have a better understanding of the situation.

This article reports the findings of the first step of four steps of a designbased research cycle, which consists of the analysis of practical problems by 
researchers and practitioners working in collaboration with each other. As the first step of design-based research (DBR), the goals of this study are to discover the problems encountered by teachers teaching English to computer science students, and how to overcome such problems. Practically, this research contributes to the professional development in the English language training intended to the non-English background teachers.

\section{Theoretical framework}

The focus of this study (final goal) is developing a model to improve English teachers' pedagogical competency in the computer science department of universities. Thus this study employed design-based research on the grand design theory. Andriessen (2008) argues that designed-based research (DBR) is not a research approach nor a methodology, although some claim that it is a methodology, while others say it is a paradigm. Andriessen bases his ideas on the argument that DBR may make use of various methodologies. He furthermore concludes that design-based research functions as research in order to answer a particular type or research problem, which is the design problem. In line with that, Jacobsen (2016) states that DBR as a collection of methodological principles and approaches to studying innovative educational interventions in complex, real-world settings bridges the theory-practice gap. DBR emphasizes that teachers, learners, and context do matter. Barab, Arici \& Jackson (in Jacobsen, 2016) state that informed by theory and aiming at contributing to theory (as well as to educational innovation), DBR outweighs developing and testing particular interventions.

DBR includes phases to develop the design. McKenney and Reeves (2012) outline three steps in the process of DBR (Figure 5): 1) analysis and exploration, 2) design and construction, and 3) evaluation and reflection. These three phases are further explained by Jacobsen (2016) based on her study involving a doctoral student aiming at solving a problem about low student engagement and the proposed solution to engage students in the design of digital games. In the analysis process, it included a review of the research literature on student engagement, situated learning and identified the possible way out for increasing student engagement and sponsoring learning. In this phase, the researchers concentrate on problem identification and diagnosis.

The next step is design and construction. In this phase, the research team thinks about background knowledge about the problem and any potential solutions to the design stage. This design is then developed in the construction process through repetitive process o prototyping approach in the classroom with feedback cycles to improve the solutions and make it better.

The last phase, evaluation and reflection, requires the researchers to gather information about the impact of the design after its implementation through iterative cycles of the design to determine the local impact. Since DBR 
is part of participatory research, the researchers and teachers work hand in hand to collect the data and analyze them for the sake of evaluation and its implementation. In doing so, the writers, as the researchers, collaborated with four teachers, who teach English for computer science students from two different universities located in the urban and suburban areas in two provinces in Indonesia, to find and analyze the problems encountered in their instructional practices.

Based on a study conducted by interviewing and observing some English teachers at the Computer Science Department of a private university some lacked of skills such as teachers had a not well-thought-out, informed approach to language teaching, did not understand and use a wide variety of techniques and did not efficiently design and execute lesson plans (Lestariningsih, 2017). All of which belong to the characteristics of a good English language teacher proposed by Brown (2007). Thus Brown's characteristics of a good language teacher were employed as the base theory of this study.

Brown (2007) lists 30 characteristics of a good English language teacher, divided into 4 categories: technical knowledge, pedagogical knowledge, interpersonal knowledge, and personal qualities. Among them, the characteristics of pedagogical skills outnumber the other skills; there are 12 characteristics, which equal to $40 \%$ compared to technical knowledge $(20 \%)$, interpersonal knowledge (23\%), and personal qualities (17\%). They do not only outnumber but also outweigh the others because they have multiple effects in which the students will, to some extent, imitate what have been done by the teachers. Based on the preliminary study conducted by interviewing and observing some English teachers in the Computer Science Department, some lacked these pedagogical skills, for example teachers had a not well-thoughtout, informed approach to language teaching, did not understand and use a wide variety of techniques, and did not efficiently design and execute lesson plans and Brown's characteristics of a good language teacher as.

\section{METHOD}

This study used a questionnaire, observation, and interview to collect data. Twenty-two questions, in the form of a questionnaire, were addressed to four teachers of English to computer science students in two universities. The universities were chosen because they shared the same characteristic: the students must in advance take general English before taking English for Specific Purposes (ESP) class. Among the teachers, only three would be participating in the next study (training) since one teacher would no longer teach ESP for computer science students. However, the result of the questionnaire of all four was recorded and then analyzed.

The teachers were equally shared with educational backgrounds. Two were graduates of English education departments, whereas the other two were 
from the computer science field. Their experience in teaching ESP was also similar, less than ten years. Two English for computer science teachers, whose academic backgrounds are from the English language education and from the computer science department, were observed during the First Semester of the Academic Year of 2017/2018; whereas one teacher was observed during the Second Semester of the Academic Year of 2017/2018. The observation was conducted both in the class (at the beginning of the semester, and almost at the end of the semester) and during the discussion. One teacher (Teacher A) was finally not included in this study since she did not teach English for Computer Science in the two semesters mentioned.

To sharpen the analysis, the observation was one of the data collection techniques employed in this study. The focus of the observation was on the 12 pedagogical skills or characteristics of good-language teaching proposed by Brown (2007). They include teachers have a well-thought-out, informed approach to language teaching, understand and use a wide variety of techniques, efficiently design and execute lesson plans, monitor lessons, effectively perceive students' linguistic needs, give optimal feedback to students, stimulate interaction, cooperation, and teamwork in the classroom, use appropriate principles of classroom management, use effective, clear presentation skills, creatively adapts textbook material and other audio, visual, and mechanical aids, innovatively create brand-new materials when needed, and use interactive, intrinsically motivating techniques to create effective tests.

\section{Teacher's reflective assessment}

Table 1 summarizes some background information of the participants. The English proficiency, proven by the proficiency test, shows that one teacher (Teacher D) was not identical in the English proficiency.

Table 1. Participants background

\begin{tabular}{|c|c|c|c|c|c|}
\hline Participant & $\begin{array}{l}\text { Educational } \\
\text { Background }\end{array}$ & $\begin{array}{l}\text { ESP } \\
\text { Teaching } \\
\text { Experience }\end{array}$ & $\begin{array}{l}\text { English } \\
\text { Proficiency }\end{array}$ & $\begin{array}{l}\text { Score } \\
\text { Interpretation }\end{array}$ & $\begin{array}{l}\text { Score } \\
\text { Equivalence }\end{array}$ \\
\hline Teacher A & $\begin{array}{l}\text { Computer } \\
\text { Science }\end{array}$ & $\begin{array}{l}\text { Less than } 5 \\
\text { years }\end{array}$ & $\begin{array}{l}94 \text { (IBT) - } \\
\text { Range: 0-120 }\end{array}$ & $\begin{array}{l}\text { Proficient user } \\
\text { of English }\end{array}$ & $\mathrm{ITP}=587$ \\
\hline Teacher B & $\begin{array}{l}\text { Computer } \\
\text { Science }\end{array}$ & $\begin{array}{l}\text { Less than } 10 \\
\text { years }\end{array}$ & $\begin{array}{l}620 \text { (ITP) - } \\
\text { Range } 320- \\
677\end{array}$ & $\begin{array}{l}\text { Proficient user } \\
\text { of English }\end{array}$ & $\mathrm{IBT}=105$ \\
\hline Teacher C & $\begin{array}{l}\text { English } \\
\text { Education }\end{array}$ & $\begin{array}{l}\text { Less than } 5 \\
\text { years }\end{array}$ & $\begin{array}{l}600 \text { (ITP) - } \\
\text { Range } 320- \\
677\end{array}$ & $\begin{array}{l}\text { Proficient user } \\
\text { of English }\end{array}$ & $\mathrm{IBT}=100$ \\
\hline Teacher D & $\begin{array}{l}\text { English } \\
\text { Education }\end{array}$ & $\begin{array}{l}\text { Less than } 10 \\
\text { years }\end{array}$ & $\begin{array}{l}59 \text { (TOEP) - } \\
\text { Range } 0 \text { - } \\
100\end{array}$ & $\begin{array}{l}\text { Independent } \\
\text { user of English }\end{array}$ & - \\
\hline
\end{tabular}

Note:

IBT = Internet-Based Test (Test of English as a Foreign Language 
Lestariningsih, E., Madya, S., \& Nurkamto, J. (2020). Pedagogical problems encountered by teachers of English to Computer Science students in the Indonesian context. EduLite: Journal of English Education, Literature, and Culture, 5 (1), 1-13. DOI: http://dx.doi.org/10.30659/e.5.1.1-13

ITP $=$ Institutional Testing Program

TOEP $=$ Test of English Proficiency

Teacher $\mathrm{A} \quad=$ ESP teacher with computer science background

Teacher B = ESP teacher with computer science background

Teacher C = ESP teacher with English education background

Teacher D = ESP teacher with no English education background

Question about how well the participants applied some instructional strategies results as follows:

Table 2. Participants background

\begin{tabular}{llcccc}
\hline No & \multicolumn{1}{c}{ Instructional Strategies } & Teacher & Teacher & Teacher & Teacher \\
& & A & B & C & D \\
\hline 1. & $\begin{array}{l}\text { Using English as the medium of } \\
\text { instruction }\end{array}$ & very good & Good & very good & good \\
\hline 2. & Applying various teaching styles & good & Sufficient & good & good \\
\hline 3. & $\begin{array}{l}\text { Applying knowledge on learning } \\
\text { styles }\end{array}$ & good & Poor & good & good \\
\hline 4. & Using various teaching techniques & sufficient & Poor & good & sufficient \\
\hline 5. & $\begin{array}{l}\text { Applying knowledge on classroom } \\
\text { management }\end{array}$ & good & Sufficient & good & sufficient \\
\hline 6. & Using various evaluation methods & good & Good & good & good \\
\hline 7. & Using teaching aids & good & Good & very good & good \\
\hline 8. & Using suitable instructional & good & Good & very good & good \\
& materials & & & \\
\hline
\end{tabular}

Table 2 shows that teachers' individual assessment on their English mastery is supported by the results of their English proficiency test, like teacher A, whose score for IBT is 94 (considered as a high score), who said that she was quite sure that her English was very good when she used it as the language of instruction in the class. Applying teaching techniques, on the other hand, is in reverse with the English proficiency. Teacher B, for instance, acknowledged that he did not use various teaching techniques in the class. This fact is also true for applying knowledge to managing class. Two teachers answered that they were good at it, whereas two others only said adequate. Generally, Table 2 informs us that point 1, 6, 7, and 8 share similar answers, which are good and very good, while the answers for the other points are only good, sufficient, and not good.

In answering the question of whether teaching ESP is easy or challenging, all of the teachers agreed that teaching ESP to students of the computer science major was both challenging and interesting. In one hand it was challenging for the non-computer science major teachers since they were almost blind from the computer science content. For the English computer science major teachers, on the other hand, they admitted it was much challenging since they were not good at teaching methodologies. The fact that non-English education background teachers were having problems in teaching 
methodologies, such as classroom management, instructional techniques, and how to engage students, was strengthened by the observation conducted in the classroom, which is shown in Table 3.

\section{Initial teacher's pedagogical skills}

Discussion among the teachers and the researcher was one of the most important steps in this study since the teachers were expected to conduct classroom action research (CAR) during the semester. The CAR, applying Kemmis and Taggart action research cycles, was conducted in three cycles based on the findings in each cycle. However, the thorough result of the CAR done by the teachers is not included in this article.

A finding with teacher A was concerning the approach to language teaching. It was found out that the non-English education background teachers always used English as the medium of instruction in the classroom. He believed that using all English as the medium of instruction during the classroom activity was good, which is not wrong for those who believe in the Direct Method or Communicative Language Teaching (CLT). What was happening was then when he tried to make a joke, nobody laughed. Almost no student was active to ask questions when he wanted them to do so. The threecredit class ran in a boring atmosphere. After-class activity was not less appealing. Some students approached the teacher and asked several questions connected to the class activities that day, and the questions were addressed in Bahasa Indonesia, their native language. This finding leads to an assumption that teacher A needed to apply code-switching in the class when he found out that the class did not run well, or the students seemed not to catch the instructional process. Applying code-switching to engage students was studied by Lestariningsih (2019), who found out that students' reluctance to ask and answer questions decrease when the teacher applied code-switching during instructional activities. This finding is also strengthened by another finding that revealed adults tend to make a distinction between vocabulary comprehension (in which they preferred some first language information) and vocabulary acquisition, in which they saw some value in English only class (Macaro \& Lee, 2013).

The result of this observation strengthens the questionnaire result which shows that this teacher felt he was not good at instructional strategies, especially on applying various teaching styles, applying knowledge on learning styles, using various teaching techniques, and applying knowledge on classroom management.

The English-education background teacher (teacher B), on the other hand, used mix-languages. She often applied code-switching during the instructional process in the classroom. She usually switched the language from English to the students' mother tongue, Bahasa Indonesia, when she wanted to cheer up the class or break the ice, or when she found out that the students looked confused. By using this technique, it seemed that she could 
Lestariningsih, E., Madya, S., \& Nurkamto, J. (2020). Pedagogical problems encountered by teachers of English to Computer Science students in the Indonesian context. EduLite: Journal of English Education, Literature, and Culture, 5 (1), 1-13. DOI: http://dx.doi.org/10.30659/e.5.1.1-13

engage the students quite successfully. It could be obviously seen from the questions addressed to teachers and from the answers the teachers got when she asked some questions to the students. Another fact was by successfully mingling the students for doing some activities.

Another English-education background teacher (teacher $\mathrm{C}$ from another university) did a very different approach. Almost $90 \%$ of instruction was conducted in Indonesian. She said that the students' English mastery was not good enough to fully listen to English. The following table (Table 3) summarizes the 12 pedagogical skills observed.

Table 3. Initial pedagogical skills from observation

\begin{tabular}{|c|c|c|c|c|}
\hline \multirow[t]{2}{*}{ No } & \multirow[t]{2}{*}{ Desired Skills } & \multicolumn{3}{|c|}{ Teacher's Observed Skills } \\
\hline & & $\begin{array}{c}\text { Teacher A } \\
\text { (English education } \\
\text { background) }\end{array}$ & $\begin{array}{c}\text { Teacher B } \\
\text { (Computer science } \\
\text { background) }\end{array}$ & $\begin{array}{c}\text { Teacher } \mathbf{C} \\
\text { (English education } \\
\text { background) }\end{array}$ \\
\hline 1 & $\begin{array}{l}\text { have a well- } \\
\text { thought-out, } \\
\text { informed } \\
\text { approach to } \\
\text { language } \\
\text { teaching }\end{array}$ & $\begin{array}{l}\text { She knew some } \\
\text { approaches in } \\
\text { language teaching, } \\
\text { such as grammar } \\
\text { translation method, } \\
\text { direct method, and } \\
\text { communicative } \\
\text { approach. She was } \\
\text { not well-informed and } \\
\text { Brown's } \\
\text { characteristics of a } \\
\text { good language } \\
\text { teacher. }\end{array}$ & $\begin{array}{l}\text { Almost all } \\
\text { approaches were } \\
\text { unfamiliar. He } \\
\text { believed that the } \\
\text { nature of computer } \\
\text { science students was } \\
\text { different and Brown's } \\
\text { characteristics of a } \\
\text { good language } \\
\text { teacher as from that } \\
\text { of language students. }\end{array}$ & $\begin{array}{l}\text { The class activities } \\
\text { showed that she was } \\
\text { not familiar with } \\
\text { communicative } \\
\text { language teaching } \\
\text { methods; such activity } \\
\text { was letting the } \\
\text { students always work } \\
\text { individually. She } \\
\text { believed that the } \\
\text { students' background } \\
\text { (most are from middle } \\
\text { to lower class families) } \\
\text { could not be forced to } \\
\text { do beyond their skills. }\end{array}$ \\
\hline 2 & $\begin{array}{l}\text { understand and } \\
\text { use a wide } \\
\text { variety of } \\
\text { techniques }\end{array}$ & $\begin{array}{l}\text { She used various } \\
\text { techniques, such as } \\
\text { peer work, group } \\
\text { work, and jigsaw } \\
\text { learning. }\end{array}$ & $\begin{array}{l}\text { He used almost the } \\
\text { same techniques in } \\
\text { every meeting, i.e. } \\
\text { lecturing and letting } \\
\text { students do the } \\
\text { exercises }\end{array}$ & $\begin{array}{l}\text { The activities were all } \\
\text { teacher centered. }\end{array}$ \\
\hline 3 & $\begin{array}{l}\text { efficiently design } \\
\text { and execute } \\
\text { lesson plans }\end{array}$ & $\begin{array}{l}\text { She did have plans } \\
\text { for every lesson even } \\
\text { though they were not } \\
\text { put on paper. }\end{array}$ & $\begin{array}{l}\text { He used almost the } \\
\text { same techniques in } \\
\text { every meeting, i.e. } \\
\text { lecturing and let } \\
\text { students do the } \\
\text { exercises }\end{array}$ & $\begin{array}{l}\text { She used almost the } \\
\text { same techniques in } \\
\text { every meeting, i.e. } \\
\text { asking the students to } \\
\text { translate English texts. }\end{array}$ \\
\hline 4 & monitor lessons & $\begin{array}{l}\text { She was quite stick to } \\
\text { the instructional } \\
\text { contract (syllabus) } \\
\text { and tried to find } \\
\text { solutions and apply } \\
\text { them for any } \\
\text { problems found in } \\
\text { the class. }\end{array}$ & $\begin{array}{l}\text { He was quite firm to } \\
\text { the instructional } \\
\text { contract (syllabus), } \\
\text { but he did not care } \\
\text { enough regarding } \\
\text { students' } \\
\text { understanding. }\end{array}$ & $\begin{array}{l}\text { The activities were } \\
\text { done at a very slow } \\
\text { pace. }\end{array}$ \\
\hline 5 & effectively & She was very & He realized students' & Based on an interview, \\
\hline
\end{tabular}


EduLite Journal of English Education, Literature, and Culture

Vol. 5, No. 1, February 2020, pp. 1-13

E-ISSN: 2528-4479, P-ISSN: 2477-5304

http://jurnal.unissula.ac.id/index.php/edulite

DOI: http://dx.doi.org/10.30659/e.5.1.1-13

\begin{tabular}{|c|c|c|c|c|}
\hline & $\begin{array}{l}\text { perceive } \\
\text { students' } \\
\text { linguistic needs }\end{array}$ & $\begin{array}{l}\text { concerned for } \\
\text { students' } \\
\text { weaknesses, such as } \\
\text { vocabulary and } \\
\text { grammar masteries. }\end{array}$ & $\begin{array}{l}\text { problems in using } \\
\text { English. He } \\
\text { sometimes used } \\
\text { analogy (Computer } \\
\text { science terminology } \\
\text { to explain English } \\
\text { structure) }\end{array}$ & $\begin{array}{l}\text { she believed that } \\
\text { students were very } \\
\text { weak in linguistic } \\
\text { mastery, but she did } \\
\text { very little to increase } \\
\text { it. }\end{array}$ \\
\hline 6 & $\begin{array}{l}\text { give optimal } \\
\text { feedback to } \\
\text { students }\end{array}$ & $\begin{array}{l}\text { She, most of the time, } \\
\text { reacted to any action } \\
\text { students did in the } \\
\text { class, such as } \\
\text { commenting on } \\
\text { students' } \\
\text { performance }\end{array}$ & $\begin{array}{l}\text { Rapport between } \\
\text { teacher and the } \\
\text { students were not } \\
\text { intentionally built. }\end{array}$ & $\begin{array}{l}\text { She sometimes } \\
\text { commented orally, but } \\
\text { not in written form. }\end{array}$ \\
\hline 7 & $\begin{array}{l}\text { stimulate } \\
\text { interaction, } \\
\text { cooperation, and } \\
\text { teamwork in the } \\
\text { classroom }\end{array}$ & $\begin{array}{l}\text { She used various } \\
\text { techniques, such as } \\
\text { peer work, group } \\
\text { work, and jigsaw } \\
\text { learning. }\end{array}$ & $\begin{array}{l}\text { Most of the time, } \\
\text { students work } \\
\text { individually. Group } \\
\text { works were done } \\
\text { because it was } \\
\text { written on the } \\
\text { syllabus. }\end{array}$ & $\begin{array}{l}\text { She never checked } \\
\text { students' work and did } \\
\text { not give feedback } \\
\text { either. }\end{array}$ \\
\hline 8 & $\begin{array}{l}\text { use appropriate } \\
\text { principles of } \\
\text { classroom } \\
\text { management }\end{array}$ & $\begin{array}{l}\text { She mingled quite a } \\
\text { lot. } \\
\text { Her view was mostly } \\
\text { to all students. }\end{array}$ & $\begin{array}{l}\text { His position was } \\
\text { mostly in front of the } \\
\text { class or behind the } \\
\text { teacher's table. }\end{array}$ & $\begin{array}{l}\text { The chair arrangement } \\
\text { was always in the } \\
\text { position of classical } \\
\text { class; the time was not } \\
\text { really managed well. }\end{array}$ \\
\hline 9 & $\begin{array}{l}\text { use effective, } \\
\text { clear } \\
\text { presentation } \\
\text { skills }\end{array}$ & $\begin{array}{l}\text { She used PowerPoint } \\
\text { to present the topics. } \\
\text { At the same time, she } \\
\text { let the students ask } \\
\text { questions during the } \\
\text { presentation. }\end{array}$ & $\begin{array}{l}\text { He kept explaining } \\
\text { every topic. He } \\
\text { applied teacher- } \\
\text { centered approach. }\end{array}$ & $\begin{array}{l}\text { Her voice was loud and } \\
\text { clear. She has a good } \\
\text { rapport with students. }\end{array}$ \\
\hline 10 & $\begin{array}{l}\text { creatively adapts } \\
\text { textbook } \\
\text { material and } \\
\text { other audio, } \\
\text { visual, and } \\
\text { mechanical aids }\end{array}$ & $\begin{array}{l}\text { Most of the time she } \\
\text { used power point } \\
\text { presentation to } \\
\text { explain a certain } \\
\text { topic. }\end{array}$ & $\begin{array}{l}\text { Most of the time he } \\
\text { used power point } \\
\text { presentation to } \\
\text { explain a certain } \\
\text { topic. }\end{array}$ & $\begin{array}{l}\text { Audio, visual, and } \\
\text { mechanical aids were } \\
\text { almost never used in } \\
\text { class. }\end{array}$ \\
\hline 11 & $\begin{array}{l}\text { innovatively } \\
\text { create brand- } \\
\text { new materials } \\
\text { when needed }\end{array}$ & $\begin{array}{l}\text { She added some } \\
\text { supplementary } \\
\text { materials. }\end{array}$ & $\begin{array}{l}\text { He followed the } \\
\text { materials prepared in } \\
\text { the beginning of the } \\
\text { semester. }\end{array}$ & $\begin{array}{l}\text { She always used } \\
\text { different reading } \\
\text { passages. }\end{array}$ \\
\hline 12 & $\begin{array}{l}\text { use interactive, } \\
\text { intrinsically } \\
\text { motivating } \\
\text { techniques to } \\
\text { create effective } \\
\text { tests }\end{array}$ & $\begin{array}{l}\text { Most of the test was } \\
\text { already prepared by } \\
\text { someone else; } \\
\text { however, she could } \\
\text { add some pop-up } \\
\text { quiz relating to a } \\
\text { certain topic, such as } \\
\text { quiz on guessing } \\
\text { meaning through } \\
\text { context clues. }\end{array}$ & $\begin{array}{l}\text { He simply used other } \\
\text { teachers' prepared } \\
\text { tests and quizzes. }\end{array}$ & Not yet observed. \\
\hline
\end{tabular}


Table 4 summarizes the score of the observed pedagogical skills in numbers. There are 4 scores, one to four. Score 4 means that the skills are mostly applied and used effectively; score 3 reveals that the skills are quite often applied in the classroom. Score 2 shows that the teachers rarely used the skills whereas score 1 indicates that the skills are almost never applied. Score 36 or above is considered as a well-practiced pedagogical skill. Below score 36 tells the researcher that there should be something to do to increase the teachers' understanding and practice of Brown's characteristics of 12 pedagogical skills needed by a good language teacher.

The result indicates that none of the teachers reached score 36; the highest score was 33, approaching the good practices of pedagogical skills, whereas the other two scores were far under the highest, 19 and 17. The result signifies that their pedagogical skills needed to be increased even though there were different needs among the teachers. The difference leads the researcher to think about various techniques in designing the most appropriate training for them.

Table 4. Score of initial pedagogical skills

\begin{tabular}{clllc}
\hline No & \multicolumn{1}{c}{ Skills } & Teacher & Teacher & Teacher \\
& & A & B & C \\
\hline 1 & $\begin{array}{l}\text { have a well-thought-out, informed approach to } \\
\text { language teaching }\end{array}$ & 2 & 1 & 1 \\
\hline 2 & understand and use a wide variety of techniques & 3 & 1 & 1 \\
\hline 3 & efficiently design and execute lesson plans & 3 & 1 & 1 \\
\hline 4 & monitor lessons & 3 & 2 & 2 \\
\hline 5 & effectively perceive students' linguistic needs & 3 & 3 & 1 \\
\hline 6 & give optimal feedback to students & 3 & 1 & 2 \\
\hline 7 & $\begin{array}{l}\text { stimulate interaction, cooperation, and teamwork } \\
\text { in the classroom }\end{array}$ & 3 & 2 & 2 \\
\hline 8 & $\begin{array}{l}\text { use appropriate principles of classroom } \\
\text { management }\end{array}$ & 2 & 1 & 1 \\
\hline 9 & use effective, clear presentation skills & 3 & 2 & 3 \\
\hline 10 & $\begin{array}{l}\text { creatively adapts textbook material and other } \\
\text { audio, visual, and mechanical aids }\end{array}$ & 2 & 2 & 1 \\
\hline 11 & $\begin{array}{l}\text { innovatively create brand-new materials when } \\
\text { needed }\end{array}$ & 3 & 2 & 1 \\
\hline 12 & $\begin{array}{l}\text { use interactive, intrinsically motivating techniques } \\
\text { to create effective tests }\end{array}$ & 3 & 1 & 1 \\
\hline & $\quad$ Total & $\mathbf{3 3}$ & $\mathbf{1 9}$ \\
\hline
\end{tabular}

\section{Analysis of practical problem}

As the first step in DBR, the analysis of the problems encountered was discussed in the scheduled meetings between the researcher and the three teachers as the practitioners. The discussions were conducted every week, and at the same time both teachers were teaching three classes of English for Computer Science students respectively. The discussions were focused on the 
problems arisen in the preparation (lesson planning), execution (instructional activities in the classroom), and reflection. These three were important referring to some educational experts who argued that states that there were more skills to obtain for language teachers, such skills are for example preparation of communicative activities, organization and facilitation of communicative interaction, judgment of proper balance between fluency and accuracy, awareness of learners' errors, appropriate treatment errors, and reviewing and re-teaching when necessary (Richard \& Lockhart, 2014; Rochsantiningsih, 2004).

During the discussions, the researcher and the teachers analyzed some findings, particularly teachers' drawbacks in their 12 pedagogical skills, as proposed by Brown. The biggest problem found was their knowledge on the language teaching approaches, which according to Brown (2001) is their belief about the nature of language, the nature of language learning, and the applicability of both to pedagogical setting; thus the training, which follows, should make sure that they are well-taught or well-refreshed of the knowledge of language teaching approaches since they will be revealed in their teaching practices. Such belief was shown by one of the teachers who said that the students were too shy to use English. She also believed that because of this shyness, they could not be forced to, for instance, talk in front of the class, and they were not supposed to receive feedback. Because of this belief, she rarely asked the students to do something in front of their friends. This belief also influenced the other pedagogical skills such as understand and use a wide variety of techniques and give optimal feedback to students.

Teacher B, whose background is computer science, believed that the nature of such students is different from that of language students. Thus, he treated them the same as teaching exact subjects such as teaching mathematics, which is quite reasonable since he was not familiar with various methods and techniques in language teaching practice. Some discussions to overcome this problem could not effectively influence the teachers to try to use various methods and techniques in language teaching. This belief was gradually altered after one of the writers got their permission to once teach their classes. In the demo some techniques were applied such as finding ways to encourage students to practice their English unconsciously, working in groups, gaming, using audio-visual-mechanical aids, and giving feedback both orally and in written form. Writing a well-prepared lesson plan was also intentionally introduced by showing the teachers the plan before executing it. Through this teaching demo the two teachers found out that what they believed was not fully appropriate. In fact, they almost never tried new methods because of their assumptions. To this point, they changed their paradigm about their students. 


\section{CONCLUSION}

As one of the agents of change, teachers play a very important role in the instruction or teaching and learning process. This study shows that in-service language teachers need to increase and to revive their skills, specifically in pedagogical. This study analyzed practical problems encountered by the teachers in two private universities in the context of Indonesia. The findings show that knowledge on approaches to language teaching plays an exceptionally important part in teaching practice. This knowledge, however, cannot solely be mastered without experiencing them in relevant situations. Thus theory of andragogy (adult learning), with its principles, problem-solving, experiential, engaging, and relevant (Knowles, Holton, Swanson, 2005), should be integrated in the training design, which is the second step of design based research (development of solutions informed by existing design principles and technological innovations).

\section{ACKNOWLEDGEMENTS}

My deepest gratitude goes to all the teachers who had helpfully became the participants of this research, and to my supervisors, who had patiently guided me in this study.

\section{REFERENCES}

Andriessen, D.G. (2008). Combining design-based research and action research to test management solutions. In Towards quality improvement of Action research: developing ethics and standards, Boog B., Slagter M., Zeelen J, Preece J (eds). Rotterdam: Sense Publishers. (Pp. 125-134).

Brown, H.D. (2007). Principles of language learning and teaching. Fifth Edition. New York: Pearson.

Brown, H.D. (2001). Teaching by principles, $2^{\text {nd }}$ Edition. New York: Pearson.

Guerriero, S. (ed). (2017). Pedagogical knowledge and the changing nature of the teaching profession. Paris: OECD Publishing. http://dx.doi,org/10.1787/9789264270695-en.

Herrington, J., McKenney, S., Reeves, T., \& Oliver, R. (2007). Designed-based research and doctoral students: Guidelines for preparing a dissertation proposal. In C. Montgomerie \& J. Seale (Eds), Proceedings of World Conference on Educational Multimedia, Hypermedia and Telecommunications 2007 (pp. 4089-4097).

Jacobsen, M. (2014). December 3. Design-based research. Edcan Network Magazine. Retrieved March 14, 2017, from https://www.edcan.ca/articles/design-based-research/ 
EduLite Journal of English Education, Literature, and Culture

Vol. 5, No. 1, February 2020, pp. 1-13

E-ISSN: 2528-4479, P-ISSN: 2477-5304 http://jurnal.unissula.ac.id/index.php/edulite DOI: http://dx.doi.org/10.30659/e.5.1.1-13

Knowles, M., Holton, E. F., \& Swanson, R. A. (2005). The adult learner. (6 ${ }^{\text {the }}$ d). Burlington, M.A.: Elsevier Inc.

Lestariningsih, F.E. (2019). The effect of code switching on engaging nonEnglish major students. International Journal of Indonesian Education and Teaching. 3(2). doi.org/10.24071/ijiet.2019.030206.

Lestariningsih, F.E. (2017). The needs of English for specific purposes teachers with and without English language education backgrounds. Proceedings of Conference on Language and Language Teaching. Retrieved from https://semnas.untidar.ac.id/wp-content/uploads/2018/02/page178-183-fransisca.pdf

Macaro, E. \& Lee, J.H. (2013). Teacher language background, codeswitching, and English only instruction: Does age make a difference to learners' attitudes?. TESOL Quarterly. 47(4). https://doi.org/10.1002/tesq.74

Miri, B., David, B., Uri, Z. (2007). Purposely teaching or the promotion of higher-order thinking skills: A case of critical thinking. Res Sci Educ, 37.353-369. Doi 10.1007s11165-006-9029-2

Richards, J.C., \& Rodgers, T.S. (2014). Approach and methods in language teaching. Second Edition. Cambridge: Cambridge University Press.

Richards, J.C. \& Lockhart, C. (2007). Reflective teaching in second language classrooms. New York: Cambridge University Press.

Rochsantiningsih, D. (2004). Enhancing professional development of Indonesian high school teachers through action research. A dissertation. Macquarie University.

Universitas Kristen Duta Wacana. (2016). Laporan akhir program hibah pusat karir lanjutan. unpublished document. Yogyakarta.

Universitas Kristen Duta Wacana. (2016). Informasi \& profil kemahasiswaan tahun akademik 2016/2017. unpublished document. Yogyakarta. 